\title{
Erythropoietin Stimulates Vasculogenesis in Neonatal Rat Mesenteric Microvascular Endothelial Cells
}

\author{
RICHARD A. ASHLEY, SUZANNE H. DUBUQUE, BOHUSLAV DVORAK, \\ SUANN S. WOODWARD, STUART K. WILLIAMS, AND PAMELA J. KLING \\ Mayo Medical School, Mayo Clinic, Rochester, Minnesota 55905 [R.A.A.]; Department of Pediatrics, \\ Steele Memorial Children's Research Center [S.H.D., B.D., S.S.W., P.J.K.]; and Department of \\ Biomedical Engineering [S.K.W.], The University of Arizona, Tucson, Arizona 85724
}

ABSTRACT

\begin{abstract}
Human breast milk is a rich source of growth factors, including erythropoietin (Epo), the endogenous hormonal stimulant of erythropoiesis. Recombinant human Epo (rhEpo) has been shown to stimulate 1) angiogenesis, the process of new blood vessel growth from preexisting vessels; 2) vasculogenesis, tubule formation from single-cell suspensions; and 3) endothelial cell proliferation in immortalized endothelial cells and vessel explants. We hypothesized that Epo would induce mitogenesis and stimulate vasculogenesis in primary cultures of microvascular endothelial cells (MVECs) from neonatal rat mesentery. Isolation, purification, characterization, and culture of MVECs were performed. Cell proliferative effects of rhEpo were studied by 3-(4,5 dimethylthiazol-2-yl)-2,5-diphenyltetrazolium bromide assay in cultured MVECs. Vasculogenic effects of rhEpo were examined on cultured MVECs plated on either hormone-rich Matrigel substratum or the extracellular matrix protein, type I collagen. Our findings show that MVECs are isolated and purified, and that rhEpo stimulates MVEC proliferation, with maximal proliferation seen with a concentration of $50 \mathrm{IU} / \mathrm{mL}$ rhEpo. Tubule formation assays reveal that an rhEpo concentration of 50 $\mathrm{IU} / \mathrm{mL}$ produces maximal tubule formation after $12 \mathrm{~h}$ on both Matrigel and the simple substratum, type I collagen. Our study is the first to examine the effects of rhEpo on the endothelium of the
\end{abstract}

neonatal gastrointestinal tract. These data suggest that Epo may have a trophic effect on the vasculature of the gastrointestinal tract early in development. Furthermore, as Epo has been measured in breast milk, and its receptor has been shown to exist on the mucosa and gastrointestinal vasculature, Epo may be an endogenous stimulant of vessel growth during neonatal gastrointestinal development. (Pediatr Res 51: 472-478, 2002)

\section{Epo, erythropoietin}

\section{Abbreviations}

rhEpo, recombinant human erythropoietin

EpoR, erythropoietin receptor

MVECs, microvascular endothelial cells

vWF, von Willebrand factor

DiI-Ac-LDL, fluorescently modified LDL analog

MTT, 3-(4,5 dimethylthiazol-2-yl)-2,5-diphenyltetrazolium bromide

NEC, necrotizing enterocolitis

HUVEC, human umbilical vein endothelial cell

M-199, media-199

$\mathbf{P} / \mathbf{S}$, penicillin/streptomycin

MEC, complete media for endothelial cells

DIC, differential interference contrast
Many growth factors and hematopoietic cytokines have been measured in human breast milk (1-4). Epo, the primary hormonal stimulant of red blood cell production, is among this group of substances (5). As it does for other growth factors, human milk protects Epo from proteolytic degradation (5). The EpoR is present in the brush border and vascular endothelium

Received April 17, 2001; accepted August 7, 2001

Correspondence and reprint requests: Pamela J. Kling, M.D., Division of Neonatology, Department of Pediatrics, University of Wisconsin and Meriter Hospital, 202 S. Park Street, Madison, WI 53715; e-mail: pjkling@facstaff.wisc.edu

Supported by the American Heart Associate, South West Affiliate (SW-GS-16-98, P.J.K.), NIH Program Project Grant (HD-26013, P.J.K., B.D.), and National Institutes of Child Health and Human Development Grant (\#2-T35-HDO744-08, R.A.) as part of a fellowship from the American Pediatric Society/Society for Pediatric Research. of the mucosa lining the small intestine (6). Because endothelial cells and erythropoietic cells are derived from the same progenitor cell, the hemangioblast, it is possible that Epo exerts similar trophic effects on endothelium as it does on erythropoietic cells (7). Milk-borne Epo has been shown to be absorbed without degradation (6). These data suggest that Epo may act as a stimulator of normal development of the digestive tract.

Among its many potential effects, Epo may stimulate angiogenesis, the process by which preexisting blood vessels give rise to new vessels. During angiogenesis, proteins from vascular endothelial cells degrade the extracellular matrix, migrate into perivascular space, proliferate, align themselves into tu- 
bular vessels, and form a vascular lumen (8). An in vitro vasculogenesis model is used to study angiogenesis by assessing tubule formation in either Matrigel substratum or type 1 collagen extracellular matrix $(7,8)$. Studies have shown that rhEpo induces endothelial cell proliferation, stimulates angiogenesis, and improves blood flow in vivo (9). Further in vitro studies have shown that rhEpo stimulates endothelial cells from rat aorta transections to form new vessels (10). In endothelial cells, rhEpo may bind the EpoR and activate the JAK-2 and STAT-5 pathways, similar to that seen in erythropoietic cells (7).

Mesenteric vessels provide crucial blood supply required for gastrointestinal tissue nutrition and oxygenation during embryonic and fetal development. If milk-borne Epo is absorbed enterally, stimulating vessel growth in the immature digestive tract, the risk for local tissue hypoxia may be lessened. We have shown that a relatively high percentage of rhEpo remains in the wall and vascular bundle of the small intestine after enteral administration (11), but thus far, the precise biologic effects of milk-borne Epo have not been identified.

In this study, we tested the hypothesis that rhEpo can induce vasculogenesis in the neonatal rat mesentery. Previous work has shown that endothelial cells from rat mesentery can be harvested and studied in vitro (12). We isolated and characterized MVECs from the neonatal rat mesentery. Once identity of cultured MVECs was assured, we observed the effects of rhEpo on proliferation and tubule formation in this cellular population.

\section{METHODS}

Cells. The Animal Care and Use Committee of the University of Arizona approved this protocol. MVECs were isolated from the mesentery of 6-d-old inborn neonatal rats (SpragueDawley, Charles Rivers Labs, Hollister, CA, U.S.A.) from litters culled to 10 after birth, following the protocol described by Snead et al. (12). Briefly, animals were anesthetized with ketamine and xylazine and were killed by decapitation. The cleansed abdomen was opened, and the heart was perfused with $10 \mathrm{~mL}$ of PBS to remove circulating blood cells from the mesenteric vessels. The intestine was isolated from the abdominal cavity, and the mesentery was removed and placed in a sterile centrifuge tube containing M-199 and 1\% P/S (12). Mesentery was digested with a $0.02 \%$ collagenase solution for $1 \mathrm{~h}$ at $37^{\circ} \mathrm{C}(12)$. The resulting suspension was divided between two centrifuge tubes containing M-199, rinsed, and centrifuged. Pelleted cells were resuspended in MEC media containing M-199, 5\% FCS, 5\% FBS, 1\% endothelial cell growth factor, $1 \% \mathrm{P} / \mathrm{S}$, and $1 \%$ heparin and plated on $0.5 \%$ gelatin-coated T-25 plates (12). Two hours later, nonadherent cells were removed, and the adherent, endothelial cells remained. After 4-5 d, MVECs reached confluence and were transferred to $0.5 \%$ gelatin-coated T-75 plates. Cells from the third passage were used for all assays described below. Materials were purchased from Sigma Chemical Co. (St. Louis, MO, U.S.A.), with the exception of endothelial cell growth factor (Roche, Indianapolis, IN, U.S.A.) and M-199 (GIBCO,
Rockville, MD, U.S.A.). rhEpo was purchased from Amgen (Thousand Oaks, CA, U.S.A.).

Endothelial cell characterization. The cells were identified as endothelial cells by immunofluorescence microscopy and flow cytometry. HUVECs were used as control cells. All microscopy was performed with $70-80 \%$ confluent cells in two-well chamber slides $\left(4 \mathrm{~cm}^{2}\right.$ area) coated with $0.5 \%$ gelatin (Lab-Tek, Nalgene, Rochester, NY, U.S.A.). MVECs were immunolabeled for the endothelial cell marker, vWF (SC8068, Santa Cruz Biotechnology, Santa Cruz, CA, U.S.A.). Briefly, cells were fixed with a $2.5 \%$ formaldehyde solution for $20 \mathrm{~min}$, washed with PBS three times for $10 \mathrm{~min}$ each, and blocked for $20 \mathrm{~min}$ with $1 \%$ nonfat dry milk in PBS at room temperature. Slides were incubated with the primary antibody $(1: 100)$ at $37^{\circ} \mathrm{C}$ with $5 \% \mathrm{CO}_{2}$ for $1 \mathrm{~h}$, followed by three more washes in PBS for 10 min each. Next, the samples were fluorescently labeled with the FITC-conjugated secondary antibody to vWF (donkey anti-goat IgG, SC-2042, Santa Cruz Biotechnology) for $1 \mathrm{~h}$ at room temperature. Cells were visualized by fluorescence microscopy using standard fluorescein filters (Leica laser-scanning confocal microscope, model TCS4D, Solms, Germany).

DiI-Ac-LDL (Biomedical Technologies, Stoughton, MA, U.S.A.) is an LDL analog known to undergo endocytosis by the scavenger receptor specific to endothelial cells and macrophages/monocytes. After internalization, DiI-Ac-LDL is metabolized by endothelial lysosomes, a property used to confirm identity of the MVECs (13). Cells were grown to $70-80 \%$ confluence in the two-well chamber slides coated with $0.5 \%$ gelatin and incubated with $10 \mu \mathrm{g} / \mathrm{mL}$ of DiI-Ac-LDL in MEC media for $4 \mathrm{~h}$ at $37^{\circ} \mathrm{C}$. After incubation, the media was removed, and the cells were washed three times with MEC. Cells were then fixed, visualized, and compared with HUVEC controls as described above.

Further cellular characterization was performed by flow cytometry (BD FACScan, Becton Dickenson, San Jose, CA, U.S.A.). Endothelial cells were labeled with primary antibodies to vWF (as above) and to EpoR (SC-697, Santa Cruz Biotechnology). Endothelial cells $\left(1 \times 10^{6}\right)$ were placed in a polystyrene tube in a final volume of $100 \mu \mathrm{L}$ of PBS. Briefly, each sample was incubated with the primary antibody for $20 \mathrm{~min}$ on ice. After the incubation, cells were washed with $100 \mu \mathrm{L}$ of PBS and centrifuged (3000 rpm) at $4^{\circ} \mathrm{C}$ for $10 \mathrm{~min}$. Next, the secondary antibody for vWF (as above) and for EpoR (goat anti-rabbit IgG, SC-2040, Santa Cruz Biotechnology), were conjugated to FITC and added to the cells for $20 \mathrm{~min}$ on ice. Washing and centrifugation was repeated. Cells were then fixed in $2.5 \%$ paraformaldehyde and examined. Speciesspecific $\operatorname{IgG}$ isotype controls were used.

Endothelial cell proliferation assay. This experiment is a quantitative dye assay developed by Mosmann (14) that uses MTT to measure total cell viability after rhEpo treatment. Cells in the third passage at $70-80 \%$ confluence were plated at a density of $2 \times 10^{3}$ cells per well on $0.5 \%$ gelatin-coated 96-well plates in a total volume of $100 \mu \mathrm{L}$ of serum-deprived starvation media containing only M-199, $1 \% \mathrm{P} / \mathrm{S}$, and $1 \% \mathrm{FBS}$. The next day, the media was replaced with M-199 supplemented with 5\% FBS and 5\% FCS, as well as various concen- 
trations of rhEpo, ranging from $0,5,10,50$, and $100 \mathrm{IU} / \mathrm{mL}$, in triplicate or quadruplicate wells. The mean Epo concentration of media with $10 \% \mathrm{FBS}$ or $10 \% \mathrm{FCS}$ is $0.0011 \mathrm{IU} / \mathrm{mL}$, well below the concentrations of rhEpo added. After a 48-h incubation, cells were placed in starvation media and $20 \mu \mathrm{L}$ of MTT (5 mg/mL in PBS) (15). The cells were then incubated with $100 \mu \mathrm{L}$ of DMSO overnight, and colorimetric development was analyzed by a Dynamax spectrophotometer (model MR 580, Dynatech Plate Reader Spectrophotometer, Alexandria, VA, U.S.A.) at $630 \mathrm{~nm}$.

Matrigel tubule formation assay. Cells in their third passage (70-80\% confluent) were placed for $48 \mathrm{~h}$ in starvation media. Cells were plated at $1 \times 10^{5}$ cells $/ \mathrm{mL}$ on two-well chamber slides precoated with $8 \mathrm{mg} / \mathrm{mL}$ Matrigel (BD Bioscience, Bedford MA, U.S.A.) in M-199 with 1\% $\mathrm{P} / \mathrm{S}$ and $1 \%$ heparin (7). Matrigel is a growth matrix known to support the development of tubules from single MVECs (16). Cells were grown with escalating concentrations of rhEpo, in duplicate or triplicate chambers, ranging from 0 , $5,10,50$, and $100 \mathrm{IU} / \mathrm{mL}$ of rhEpo in M-199 supplemented with 5\% FBS and 5\% FCS. rhEpo-treated cells were incubated at $37^{\circ} \mathrm{C}$ with $5 \% \mathrm{CO}_{2}$ and examined at 2, 4, 6, 12, and $24 \mathrm{~h}$. Images of cellular morphology were collected using DIC microscopy (Olympus IMT-2 inverted microscope, Melville, NY, U.S.A.) and a Hammamatsu-Orca 100 chargecoupled device camera. Image analysis was done using Simple PCI (C-Imaging, Inc., Compix, Inc., Pittsburgh, PA, U.S.A.). Tubules, defined as elongated structures containing one or more endothelial cell bodies that are at least $100 \mu \mathrm{m}$ in length (17), were counted manually and expressed as number of tubules per $4-\mathrm{cm}^{2}$ chamber. All tubules from each chamber were counted.
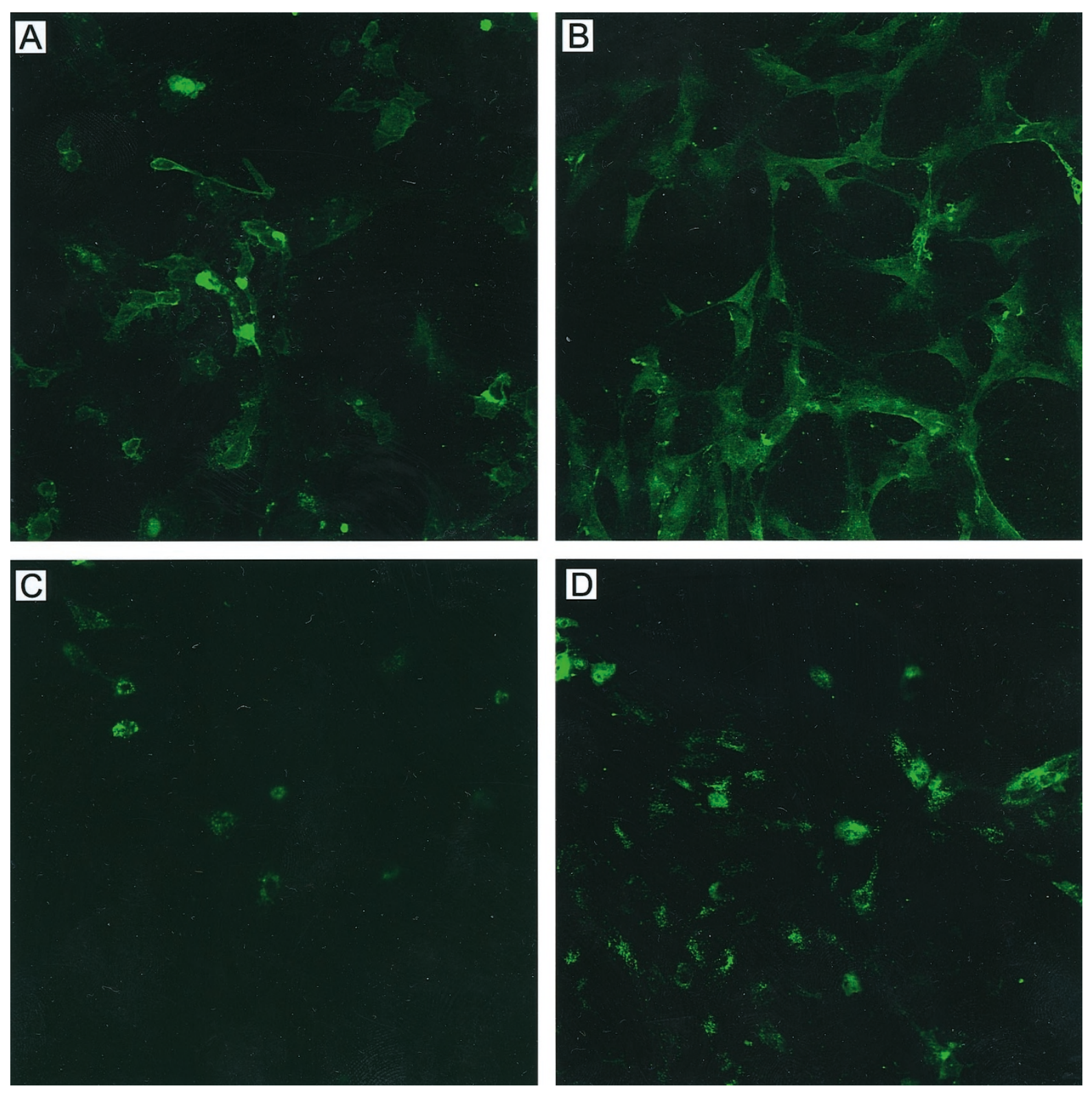

Figure 1. HUVECs $(A)$ and MVECs $(B)$ stained for cell surface vWF, with immunofluorescent staining localized to cell surface for vWF. HUVECs $(C)$ and MVECs $(D)$ stained for perinuclear DiI-Ac-LDL, with perinuclear fluorescence seen after internalization of DiI-Ac-LDL. 
Collagen tubule formation assay. We examined tubule formation in type I collagen isolated from rat tail tendon (BD Biosciences, Bedford MA, U.S.A.) following manufacturer's guidelines. Cells in their third passage were starved for $48 \mathrm{~h}$ as previously described. MVECs were plated at $1 \times 10^{5}$ cells $/ \mathrm{mL}$ on two-well chamber slides. Slides were precoated with 10 $\mu \mathrm{g} / \mathrm{cm}^{2}$ of type I collagen. Cells on duplicate slides were plated in either 0 or $50 \mathrm{IU} / \mathrm{mL}$ rhEpo in M-199 supplemented with 5\% FBS and $5 \%$ FCS. As above, cells were incubated at $37^{\circ} \mathrm{C}$ with $5 \% \mathrm{CO}_{2}$, and examined at $2,4,6,12$, and $24 \mathrm{~h}$ of growth time, with tubule number determined as above.

Data analysis. Data were expressed as mean \pm SEM. Multiple comparisons were analyzed by one-way, factorial ANOVA with Fisher's exact test post hoc testing. Single comparisons were accomplished by unpaired $t$ tests. Significance was considered to be $p<0.05$. StatView 4.1 software (Abacus Concepts, Inc., Berkeley, CA, U.S.A.) for Macintosh was used in these applications.

\section{RESULTS}

Endothelial cell characterization. Immunofluorescent studies showed that cells isolated from the neonatal rat mesentery were primarily endothelial cells. We observed at least $21 \%$ of gated cells staining positively with flow cytometry, with Figure $1, A$ and $B$, showing microscopic cell surface staining for $\mathrm{vWF}$. Figure 1, $C$ and $D$, displays characteristic microscopic perinuclear staining with DiI-Ac-LDL. A representative histogram shown in Figure 2 displays EpoR expression, as measured via flow cytometry, with $84 \%$ of gated cells staining positively.

Endothelial cell proliferation assay. As MTT is metabolized by the mitochondria of the MVECs, colored formazan product is produced, which directly correlates to the total number of viable cells. Figure 3 demonstrates absorbance of treated cells at $630 \mathrm{~nm}$, representing the amount of colored formazan product versus rhEpo concentration. Absorbance increases as the concentration of rhEpo is raised from 0 to 50 $\mathrm{IU} \mathrm{rhEpo} / \mathrm{mL}$ of media, suggesting increased proliferation with

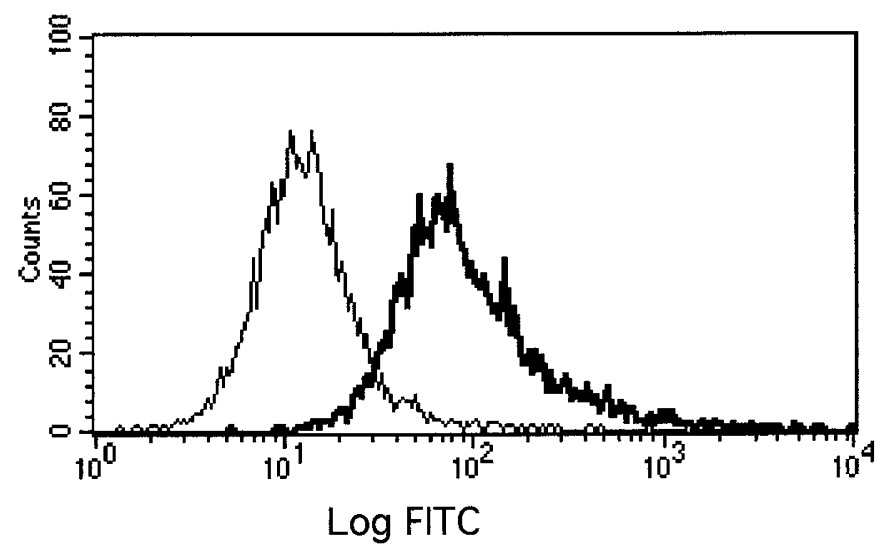

Figure 2. Representative histogram of EpoR expression on MVECs, as analyzed via flow cytometry. Cell count is represented on the vertical axis and fluorescence intensity represented on the horizontal axis. The peak on the left (light-density line) represents staining seen with the isotype-matched control antibody, and the peak on the right (bolder line) represents staining seen with anti-EpoR antibody.

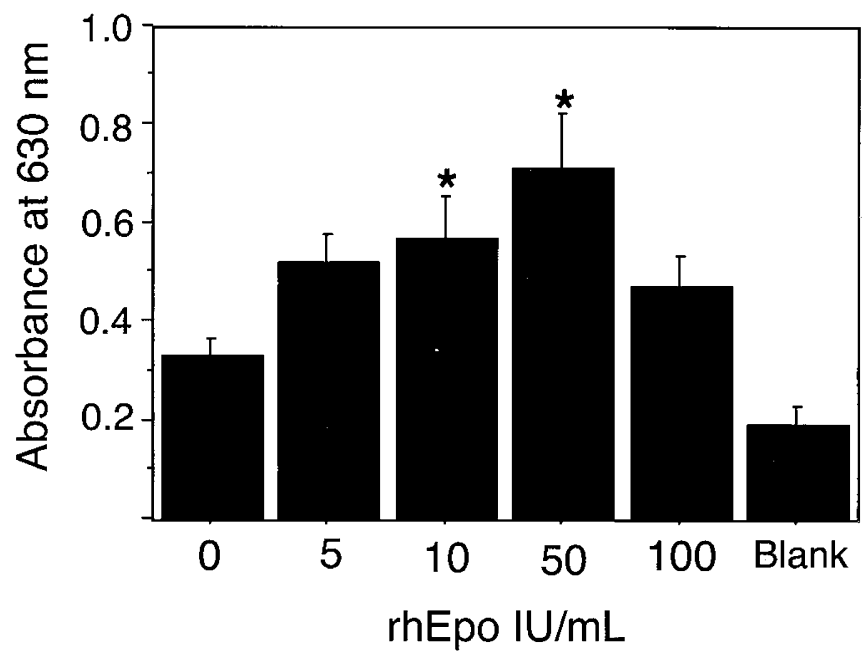

Figure 3. MTT proliferation assay showing MVEC proliferation after $2 \mathrm{~d}$ on $0.5 \%$ gelatin. Mean \pm SEM absorbance is shown on the vertical axis with concentration of rhEpo on the horizontal axis. In $n=14$ wells from four separate experiments and two different endothelial cell isolates, proliferation is affected by rhEpo concentration $\left(F_{5,78}=6.71, p<0.0001\right)$. Peak MVEC proliferation occurs at $50 \mathrm{IU} / \mathrm{mL}$ rhEpo when compared with $0 \mathrm{IU} / \mathrm{mL}\left({ }^{*} p<\right.$ 0.05 by post hoc testing).

increasing concentrations of rhEpo treatment $(p<0.0001$, by ANOVA). Maximum cell division occurs with $50 \mathrm{IU}$ rhEpo $/ \mathrm{mL}$ of media (stars indicating significance $p<0.05$ compared with untreated, 0 rhEpo).

Matrigel tubule formation assay. The response of the MVECs to rhEpo is depicted in Figures 4-6. Figure 4 demonstrates tubule number increases in a dose-response to rhEpo concentrations at $12 \mathrm{~h}$ of incubation. The mean number of tubules increase with escalating rhEpo concentrations, with peak production at $50 \mathrm{IU} / \mathrm{mL}$ rhEpo $(p<0.0001$ by ANOVA; stars indicate $p<0.05$, compared with untreated, 0 rhEpo).

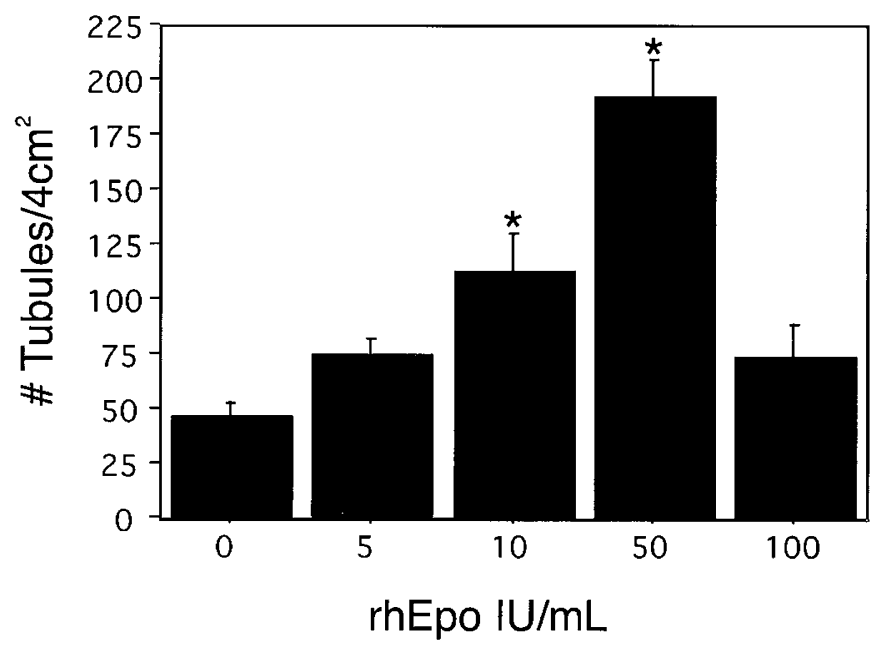

Figure 4. Tubule formation assay in Matrigel, demonstrating dose-response to rhEpo. Mean \pm SEM number of tubules formed by MVECs in each 4- $\mathrm{cm}^{2}$ well containing $8 \mathrm{mg} / \mathrm{mL}$ Matrigel. Figures are generated from seven wells in three different experiments, from two separate endothelial cell isolates. Tubule formation after $12 \mathrm{~h}$ of exposure to rhEpo is dose-dependent $\left(F_{4,30}=17.63, p\right.$ $<0.0001)$. Peak tubule formation at $12 \mathrm{~h}$ incubation occurs with $50 \mathrm{IU} / \mathrm{mL}$ of rhEpo when compared with $0 \mathrm{IU} / \mathrm{mL}(* p<0.05$ by post hoc testing). 
The DIC images obtained from cells exposed to no rhEpo (-rhEpo) over time are shown in Figure 5, $A-D$, whereas cells exposed to $50 \mathrm{IU} / \mathrm{mL}$ ( + rhEpo) over time are shown in Figure $5, E-H$, demonstrating that cells change morphology over time and rapidly develop into tubules. Tubules in the + rhEpo wells are qualitatively different and more complex than those in the - rhEpo wells. The greatest qualitative difference was at $24 \mathrm{~h}$, when tubules in the -rhEpo wells underwent drastic morphologic changes and were clumped into a mass (Fig. 5D), whereas tubules in the + rhEpo remained in complex tubules (Fig. 5H). Quantitative differences with time are also seen, based on rhEpo treatment. Mean number of tubules (Fig. 6) increases as a function of time, whether Epo is present (open bars) or not (solid bars; $p<0.0001$ for both + and - rhEpo groups, ANOVA; stars indicate $p<0.05$ compared with each group's 2-h level baseline level). Peak tubule number occurs at $12 \mathrm{~h}$ in the presence or absence of rhEpo. More tubules are seen in + rhEpo wells, compared with - rhEpo, at all times studied $(p<0.05)$.

Collagen tubule formation assay. Figure 7 demonstrates that cells plated on the extracellular matrix protein, collagen type I, also develop into tubules. At $12 \mathrm{~h}$ without rhEpo, most cells remained in typical cobblestone pattern or flat with radiating processes, with limited amounts of simple tubules formed. At $12 \mathrm{~h}$, collagen tubules in cells treated with 50 $\mathrm{IU} / \mathrm{mL}$ rhEpo were qualitatively similar to those in Matrigel.

\section{DISCUSSION}

These studies establish that rhEpo stimulates MVEC proliferation in gelatin and MVEC tubule formation in Matrigel or type I collagen. We chose to study MVECs from the neonatal rat mesentery because they give rise to the blood vessels that will ultimately nourish the intestinal mucosa. Although previous in vitro studies have shown that rhEpo induced vessel growth in endothelial cells from adult animals $(7,10)$, this is the first to report successful isolation, characterization, and Epo-induced growth and tubular formation of MVECs from neonatal rat mesentery.
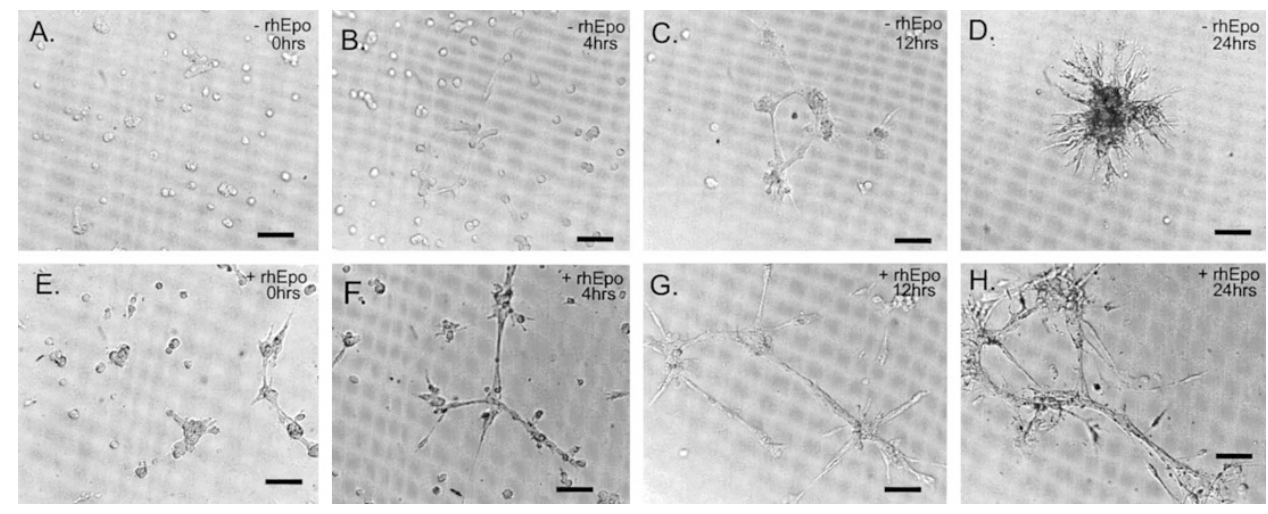

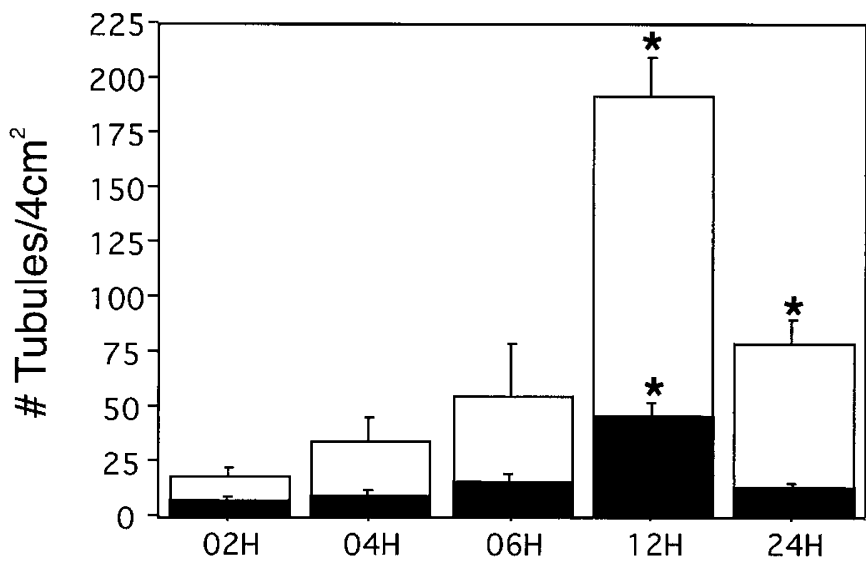

Figure 6. Time dependence observed in the tubule formation assay in 8 $\mathrm{mg} / \mathrm{mL}$ Matrigel. Mean \pm SEM number of tubules formed per $4-\mathrm{cm}^{2}$ well is on the vertical axis, and time points are shown on the horizontal axis. Results from seven wells in three different experiments, from two separate endothelial cell isolates, are shown. The tubule formation is time-dependent in the presence of $50 \mathrm{IU} / \mathrm{mL} \operatorname{rhEpo}\left(F_{4,30}=21.26, p<0.0001\right.$; open bars $)$ and without Epo $\left(F_{4,30}=17.44, p<0.0001 ;\right.$ solid bars $)$. In both groups, ${ }^{*} p<0.05$ compared with values from control wells at $2 \mathrm{~h}$ by post hoc testing.

Our data support the hypothesis that neonatal MVECs express proteins characteristic of endothelial cells. Isolated endothelial cells have been shown to range in expression of $\mathrm{vWF}$ from 10 to $80 \%$, with percentage varying based on arterial or venous side of the vessel, as well as the organ of origin (18). Gut vasculature expresses very little vWF mRNA (by quantitative reverse transcriptase-PCR), compared with other organs (18). For this reason, the LDL analog, DiI-Ac-LDL, was used to further identify our cells as endothelial cells. Endothelial cells, monocytes, and macrophages internalize DiI-Ac-LDL, but other cells, such as adipocytes, smooth muscle cells, and pericytes, do not metabolize it to the same degree (13). After perfusion of vessels before harvest, we expected systemic monocyte/macrophage numbers to be minimal. Because MVECs express EpoR, it remains feasible that MVECs bind milk-borne Epo, which is present in high levels in neonatal gastrointestinal tract.

Figure 5. Tubule formation in Matrigel at $50 \mathrm{IU} / \mathrm{mL}$ rhEpo, by DIC at $\times 10$ magnification: These images are representative of those from chambers treated without ( - rhEpo; $A-D$ ), and with $50 \mathrm{IU} / \mathrm{mL}$ rhEpo ( + rhEpo; $E-H$ ). The tubules are followed for a 24-h time course, with times listed in the upper right corner. The bar indicates $100 \mu \mathrm{m}$. $A$ and $D, 0$-h images showing scattered cells forming early tubules. $B$ and $F, 4$-h images shows developing tubules, which appear more complex in the presence of rhEpo. $C$ and $G, 12$-h image shows more elaborate tubules forming a network, which is more complex in the presence of rhEpo. $D$ and $H, 24$-h images shows complex networks are seen only in the presence of rhEpo. 
The vasculogenic process requires both proliferation and migration of the endothelial cells through the extracellular matrix, followed by alignment of the cells into tubules (8), which we tested by the MTT assay and the Matrigel assay, respectively. Serum-containing media contains small levels of Epo and other growth factors, which may be responsible for stimulation seen at baseline. Additionally, the complex basement membrane support, Matrigel, contains both epidermal growth factor and basic fibroblast growth factor, both known to be vasculogenic themselves (16). However, in the presence of rhEpo, Matrigel tubules were qualitatively more complex, greater in number, and more stable than those formed in Matrigel alone.

The response to rhEpo was dose-dependent. Erythropoietic cell lines, as well as erythropoietic marrow cells, depending on developmental stage and accompanying stimuli, vary in their responsiveness to Epo as much as several hundred-fold (19). For example, marrow colony-forming units-erythroid under standard assay conditions-have a dose-response between
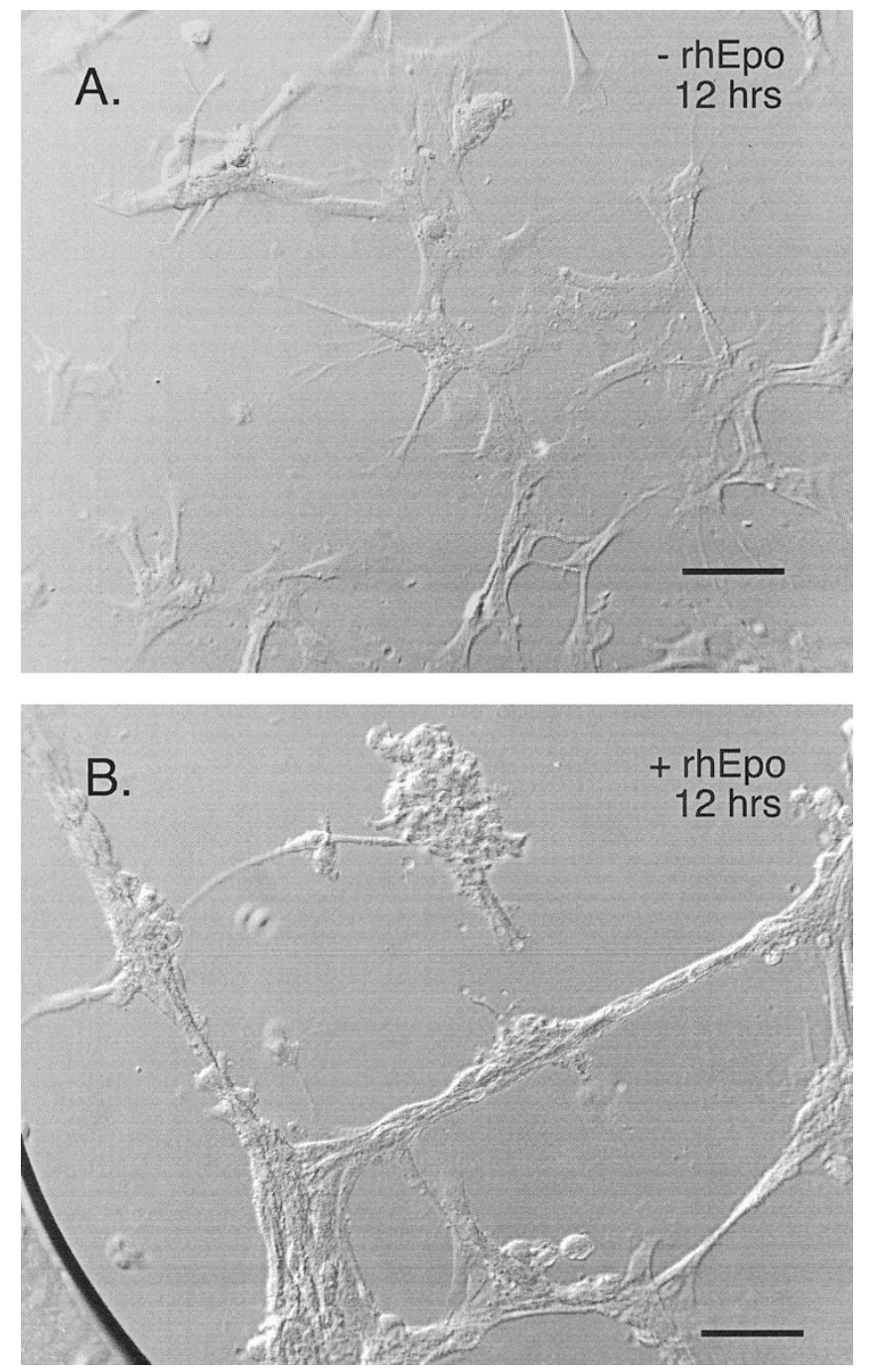

Figure 7. rhEpo causes tubule formation on collagen type I. A 12-h image showing isolated MVECs in the control well without any rhEpo $(A)$ and a $12-\mathrm{h}$ image showing more complex tubule formation after treatment with $50 \mathrm{IU} / \mathrm{mL}$ rhEpo $(B)$.
0.01 and $2 \mathrm{U} / \mathrm{mL}$; thereafter growth commonly plateaus (19). Although we were unable to find reports describing a fall in in vitro cell proliferation accompanying escalating rhEpo doses, the highest doses reported were $50 \mathrm{U} / \mathrm{mL}$ by Carlini et al. (10), similar to our study's maximal stimulation level. Our findings suggest a dose-response up to $50 \mathrm{IU} \mathrm{rhEpo} / \mathrm{mL}$ in MVECs, beyond which the pharmacologic rhEpo levels may exert intracellular toxic effects other than vasculogenesis or proliferation. Similar to our study, Carlini, et al. (10) found that tubules, although lasting somewhat longer than in our study, eventually retracted, suggesting that other factors are necessary to stabilize neovessels in Matrigel. This group has shown that rhEpo inhibits endothelial cell apoptosis (20). Similar to erythropoietic cells, second messenger pathways involving JAK-2 and STAT-5 may become activated as rhEpo binds to its receptor in endothelial cells, stimulating proliferation. Another hypothesis is that rhEpo, similar to erythropoietic cells, increases expression of the apoptosis inhibitors, Bcl- $\mathrm{X}_{\mathrm{L}}$ and Bcl-2 in endothelial cells $(20,21)$.

rhEpo may also affect endothelial cell vasculogenic responses indirectly by modulating vascular endothelial growth factor or fibroblast growth factor production or their signal transduction pathways (22). Because these growth factors stimulate vessel growth and may be present in Matrigel, type I collagen was used as a matrix for endothelial cell proliferation and migration (8). On type I collagen in the absence of rhEpo, minimal tubule formation was observed. However, in the presence of rhEpo, tubules were qualitatively similar to the Matrigel-induced tubules. Other studies using collagen (16, 17, 23) have shown that endothelial cells only form tubules on this substrate with assistance from specific growth factors (retinal growth factor, vascular endothelial growth factor, and fibroblast growth factor). Epo has not previously been shown to stimulate tubule growth independent of Matrigel.

In early development, there is a great necessity for adequate blood flow to support the growth of the immature gastrointestinal tract. The presence of EpoR on intestinal mucosa, as well as mesenteric vessels (6), along with the knowledge that Epo is present in biologically relevant levels in breast milk (5), suggests that Epo may play a role in the developing gastrointestinal tract.

Our study provides evidence that rhEpo induces proliferation and vasculogenesis in endothelial cells cultured from the neonatal rat mesentery. Because rhEpo also stimulates tubule formation independent of other growth factors on collagen, it will be necessary to further examine whether this effect is a direct effect or via stimulation of other growth factor signaling pathways. Because milk-borne Epo is absorbed enterally and may reach sufficiently high concentrations to stimulate growth of the mesenteric vasculature, these findings support ongoing study of the mechanisms involved in the effects of Epo on the vasculature of the developing gastrointestinal tract.

Acknowledgments. The authors thank Catherine Williams, M.S., K. Muy Taing, Melissa Halpern, Ph.D., Douglas Cromey, M.S., Jay Hoying, Ph.D., Alison Stopeck, M.D., Fayez K. Ghishan, M.D., and Vijay Shah, M.D., for their excellent technical assistance and support. 


\section{REFERENCES}

1. Palkowetz KH, Royer CL, Garofalo R, Rudloff HE, Schmalstieg FC, Goldman AS 1994 Production of interleukin- 6 and interleukin- 8 by human mammary gland epithelial cells. J Reprod Immunol 26:57-64

2. Goldman AS, Chheda S, Keeney SE, Schmalstieg FC, Schanler RJ 1994 Immunologic protection of the premature newborn by human milk. Semin Perinatol 18:495-501

3. Koldovsky O 1996 The potential physiological significance of milk-borne hormonally active substances for the neonate. J Mammary Gland Biol Neoplasia 1:317-322

4. Hara T, Irie K, Saito S, Ichijo M, Yamada M, Yanai N, Miyazaki S 1995 Identification of macrophage colony-stimulating factor in human milk and mammary gland epithelial cells. Pediatr Res 37:437-443

5. Kling PJ, Sullivan TM, Roberts RA, Philipps AF, Koldovsky O 1998 Human milk as a potential enteral source of erythropoietin. Pediatr Res 43:216-221

6. Juul SE, Joyce AE, Zhao Y, Ledbetter DJ 1999 Why is erythropoietin present in human milk? Studies of erythropoietin receptors on enterocytes of human and rat neonates. Pediatr Res 46:263-268

7. Ribatti D, Presta M, Vacca A, Ria R, Giuliani R, Dell'Era P, Nico B, Roncali L, Dammacco F 1999 Human erythropoietin induces a pro-angiogenic phenotype in cultured endothelial cells and stimulates neovascularization in vivo. Blood 93:2627-2636

8. Folkman J, Haudenschild C 1980 Angiogenesis in vitro. Nature 288:551-556

9. Yasuda Y, Masuda S, Chikuma M, Inoue K, Nagao M, Sasaki R 1998 Estrogendependent production of erythropoietin in uterus and its implication in uterine angiogenesis. J Biol Chem 273:25381-25387

10. Carlini RG, Reyes AA, Rothstein M 1995 Recombinant human erythropoietin stimulates angiogenesis in vitro. Kidney Int 47:740-745

11. Miller-Gilbert AL, Dubuque SH, Dvorak B, Williams CS, Grille JG, Woodward SS, Koldovsky O, Kling PJ 2001 Enteral absorption of erythropoietin in the suckling rat. Pediatr Res 2001 Aug;50(2):261-267

12. Snead MD, Papapetropoulos A, Carrier GO, Catravas JD 1996 Isolation and culture of endothelial cells from mesenteric vascular bed. Methods Cell Sci 17:257-262
13. Voyta JC, Via DP, Butterfield CE, Zetter BR 1984 Identification and isolation of endothelial cells based on their increased uptake of acetylated-low density lipoprotein. J Cell Biol 99:2034-2040

14. Mosmann T 1983 Rapid colorimetric assay for cellular growth and survival: application to proliferation and cytotoxicity assays. J Immunol Methods 65:55-63

15. Ohmi K, Kiyokawa N, Takeda T, Fujimoto J 1998 Human microvascular endothelial cells are strongly sensitive to Shiga toxins. Biochem Biophys Res Commun 251:137141

16. Nicosia RF, Ottinetti A 1990 Modulation of microvascular growth and morphogenesis by reconstituted basement membrane gel in three-dimensional cultures of rat aorta: a comparative study of angiogenesis in matrigel, collagen, fibrin, and plasma clot. In Vitro Cell Dev Biol 26:119-128

17. Xin X, Yang S, Kowalski J, Gerritsen ME 1999 Peroxisome proliferator-activated receptor $\mathrm{g}$ ligands are potent inhibitors of angiogenesis in vitro and in vivo. J Biol Chem 274:9116-9121

18. Yamamoto K, de Waard V, Fearns C, Loskutoff DJ 1998 Tissue distribution and regulation of murine von Willebrand factor gene expression in vivo. Blood 92:27912801

19. Koury MJ, Bondurant MC 1992 The molecular mechanism of erythropoietin action. Eur J Biochem 210:649-663

20. Carlini RG, Alonzo EJ, Dominguez J, Blanca I, Weisinger JR, Rothstein M, BellorinFont E 1999 Effect of recombinant human erythropoietin on endothelial cell apoptosis. Kidney Int 55:546-553

21. Haller H, Christel C, Dannenberg L, Thiele P, Lindschau C, Luft FC 1996 Signal transduction of erythropoietin in endothelial cells. Kidney Int 50:481-488

22. Alvarez Arroyo MV, Castilla MA, Gonzalez Pacheco FR, Tan D, Riesco A, Casado S, Caramelo C 1998 Role of vascular endothelial growth factor on erythropoietinrelated endothelial cell proliferation. J Am Soc Nephrol 9:1998-2004

23. Gerritsen ME, Shen C-P, Atkinson WJ, Padgett RC, Gimbrone MA, Milstone DS 1996 Microvascular endothelial cells from E-selectin-deficient mice form tubes in vitro. Lab Invest 75:175-184 